\title{
New Fiscal Package in Kosovo and Its Impact on Economy
}

\author{
Artan Nimani ${ }^{1}$ and Halil Kukaj ${ }^{1}$
}

\begin{abstract}
In order to create a more flexible system for citizens and businesses in Kosovo, the Government of Kosovo made a decision by which from 1 April 2014 increased the salaries for $25 \%$ for employees receiving salaries and pensioner compensation and other social categories from the Kosovo budget. This Government decision carries some problems with regard to public finance management and impact on the country's economy by creating a new reality in the payroll and public spending. Direct impact of this document: Decision No: 01/176. 10 March 2014, are: First, the increase in wage expenditures was not planned in the Medium Term Expenditure Framework 2014-2016 and this has given an indication of macroeconomic inefficiency (Assessed by the Kosovo Finance Ministry). Secondly, this increase decreases capital investment costs, which have the greatest potential to generate economic growth. Thirdly, wage growth along with spending on the Pristina-Skopje highway is expected to increase the budget deficit over the fiscal rule. Such a situation was also present at the time of investments in the Motorway Vermicë - "Nations connection way". In order to balance the increase of budget expenditures with revenues, the International Monetary Fund (IMF), at the conclusion of the Kosovo visit in March 2015, suggested to the Government of Kosovo that in the continuation of the increase of the various excise duties to see the possibilities for growth Value Added Tax (VAT) which would bring a substantial increase in budget revenues. At the 20th meeting of the Government of Kosovo, dated 24 March 2015, during this IMF visit, the Government took a series of decisions on fiscal changes. Among other things, these decisions have to do with the approval of new draft laws: 1. Changes in Value Added Tax (VAT); 2. Changes in Corporate Income Tax; 3. Changes in Personal Income Tax; and 4. Changes in excises duties of cars, tobacco, and alcoholic beverages etc. Based on the analysis of these changes and their effects, one can make an assessment of the economic and fiscal effects of the aforementioned laws. Some of the key findings of this study-analysis section show that small businesses will be negatively impacted by lowering the VAT threshold, while the abolition of VAT on machinery and raw materials will lower the cost of production and potentially increase investments in manufacturing sectors. Reform in fiscal policy encourages greater investment in production and at the same time improves business liquidity. According to an estimate by the Ministry of Finance, businesses will have about 27.6\% cheaper start of production process.
\end{abstract}

Keywords: Kosovo budget., VAT, Tax, IMF, Ministry of Finance, fiscal

\section{Fiscal Reform in the Republic of Kosovo}

The reform in fiscal policy is expected to boost larger investments in production and at the same time to improve the business liquidity. According to an assessment made by the Ministry of Finance, businesses will have about 27.6\% cheaper start of the production process. ${ }^{1}$

On the other hand, with regard to budgetary effects, revenues from the chapters 84 and 85 will mainly decrease, but the VAT exemption for each product will be made by a

\footnotetext{
${ }^{1}$ Ministry of Finance, Interview with Semra Turbedar and Berat Havolli, 24 April 2015.
} 
commission that is expected to be defined by an Administrative Instruction.

The new law is expected to establish procedural facilitations as it removes the obligation to extract the certificate for import and export at TAK.

What will have the meaning of a change and which is expected to have great effects on the consumer basket and on Kosovo budget revenues is the escalation of VAT. Unlike the old law where the VAT rate for most products was $16 \%$, the new VAT rate increases to $18 \%$. An equally important change in the new law is the escalation of VAT, by which the reduced VAT rate at $8 \%$ is applied to certain categories of products such as:

$\checkmark$ Food (rice, flour, white bread, milk, eggs, etc.)

$\checkmark$ Public utilities (electricity, waste collection, heating, etc.)

$\checkmark$ Supplying with medicines and medical instruments etc.

In order to have as clear as possible the effect of this fiscal change on the consumer basket, we will present the unit prices of February 2015 of a number of "more representative" articles and services published by the Kosovo Agency of Statistics.

Based on the weights used by KAS, these articles comprise about 33\% of the consumer basket.

A verified high-precision measurement of the VAT impact on prices is difficult, especially considering that the price drop of different articles as: electricity and oil, may reflect a decline in prices for domestic products, keeping other factors isolated. From this it turns out that the consumer basket will have increase in for $1 \%$.

A special attention is worth noting that: bread as a product that constitutes for about $2.75 \%$ of the consumer basket is expected to have a price drop for 2 cents, milk 6 cents, oil 8 cents, 30 eggs will drop for 17 cents while energy price will drop for 0.5 cent for kilowatt/hour.

I will give an example as an illustration: If a household spends an average of about 500 kilowatt hours of electricity per month then it will save about 2.5 euros monthly from the VAT reduction.

Except that we will have a reduction in products of family basket, there will also be some increase in products such as: meat as a major food product is expected to be more expensive for an average of 9 cents per $\mathrm{kg}$.

When we take and analyse the change, except meat also other food products became more expensive, for example: potatoes, tomatoes, beans, coffee, tea, sugar will have a price increase.

An additional burden are the oil derivatives which comprise about 3\% of the consumer basket (even more than the bread) will have an increase by about 2 cents per litter.

While regarding prices of luxury products such as cigarettes and beers etc., they will have a double increase, because they will also suffer from increased excise tax on these products. To illustrate this direct effect we give this example:

With old package one citizen has paid 24 cents excise tax per litter of beer, now he will pay 39 cents, which is an increase of $60 \%$, while for one pack of cigarettes he will pay 6 cents more only from the increase in excise tax plus 4 cents from the increase in VAT (10 cents more expensive).

Since the TAK does not have a database that divides revenues from VAT based on products and the calculation for the revenue of this institution cannot be done, so the effect of those changes On the law on VAT, in the budget revenues also not possible, 
However, According to the data received by Customs, based on the 2014 revenues, the net effect of lowering the VAT rate for some products in customs revenues is expected to be around 5 million euros. ${ }^{2}$

Product categories that are expected to have a greater impact on revenue reduction are:

- Oils and greases for cooking,

- Milk,

- Flour,

- Wheat,

- Corn, etc.

On the other hand, the VAT increase from $16 \%$ to $18 \%$ in all other products will increase customs revenues by about 51 million euros, plus 4.2 million euros in revenues from applying 8\% VAT on supplies with medicines (always talking about the direct effect of fiscal reform in 2014/2015).

\section{Effects of reduced VAT rate}

As mentioned above, the new VAT Law for the first time reduced the VAT rate on some products. While this law only regulates the categories of products on which can be applied reduced VAT of $8 \%$, the tariff codes of products with reduced VAT are specified by the Administrative Instruction. ${ }^{3}$ Based on the competencies given by the law, the Minister of Finance may extend the list of products within those categories without obtaining any approval from the Kosovo Assembly. In order to measure the effect of reducing VAT on customs revenues, we have analysed the Kosovo Customs database regarding revenues at the level of tariff codes. Taking into account the amount over which VAT of $8 \%$ is applied, from the customs revenue, a scenario would be: how much would be the customs revenue for the analysed period if in on products with reduced VAT of $8 \%$, the standard rate VAT of $18 \%$ would be applied. Based on calculations for the period January-August 2016, revenues collected from customs in these products would be around 19.1 million euros or about 10.6 million euro higher than current revenues. In other words, while on average the revenues collected from these products in the period of January-August 2016 were around 1.1 million Euros per month, with VAT of $18 \%$ would be 2.4 million euros.

Reduction of VAT on some products has also affected TAK income or domestic revenues. As seen in the chart above, in January-June 2015- 2016, TAK revenues have decreased by about 11.6 million euros. If this table would contain the collected revenues from the pharmaceutics, then the decrease in the VAT collection would be smaller. Based on a rough calculation, if the standard VAT of $18 \%$ would have been applied to these products/services, during period January-June 2016 the TAK would have collected about 7.5 million euros more revenues (in total about 13.5 million euros) compared to current revenues.

2 A accurate calculation for all customs codes cannot be done, since the Ministry of Finance has not specified the customs codes of products that benefit from the reduction of the VAT rate

${ }_{3}$ Official Gazette, Law No. 05 / L-037 On Value Added Tax, Article 29: Source: http://bit.ly/2e6J19w 4 


\section{Effects of Increased VAT Rate}

After the entry into force of the new law on VAT, the standard VAT rate has increased from $16 \%$ to $18 \%$ on most products, or $12.5 \%$ higher than before September 2015.

Based on the tariff codes of the imported products in 2015, reduced VAT was applied to about 300 customs codes, while in around 5,500 other tariff codes VAT of 18\% was applied. As expected, the increase of VAT together with the increase in import level, have reflected positively on customs revenues.

While during period January-August, Kosovo Customs have collected about 250.7 million euros from products in which standard VAT $(18 \%)$ was applied, in the same period of 2016, 318.5 million euros have been collected or about 68 million euro (27\%) more than in the same period last year.

Table 1: Revenues from standard VAT rate, before and after changes

\begin{tabular}{|l|c|}
\hline Revenues from the standard VAT rate & Amount \\
\hline January-August $2015($ TVSH $=16 \%)$ & $250,713,225 €$ \\
\hline January-August $2016($ TVSH $=18 \%)$ & $318,493,702 €$ \\
\hline Difference & $67,780,477 €$ \\
\hline
\end{tabular}

In order to measure the effect of increased VAT from $16 \%$ to $18 \%$, based on the import amount over which the standard VAT of $18 \%$ was applied, for the period SeptemberAugust 2015/2016 we applied the VAT rate of $16 \%$. Based on this we see that the customs revenues have increased on average about 4.5 million euros per month as a result of the increase in the VAT rate. Compared to the previous year, during the period January-August 2016 customs revenues have increased by about 35.4 million euros only from the increase of VAT rate.

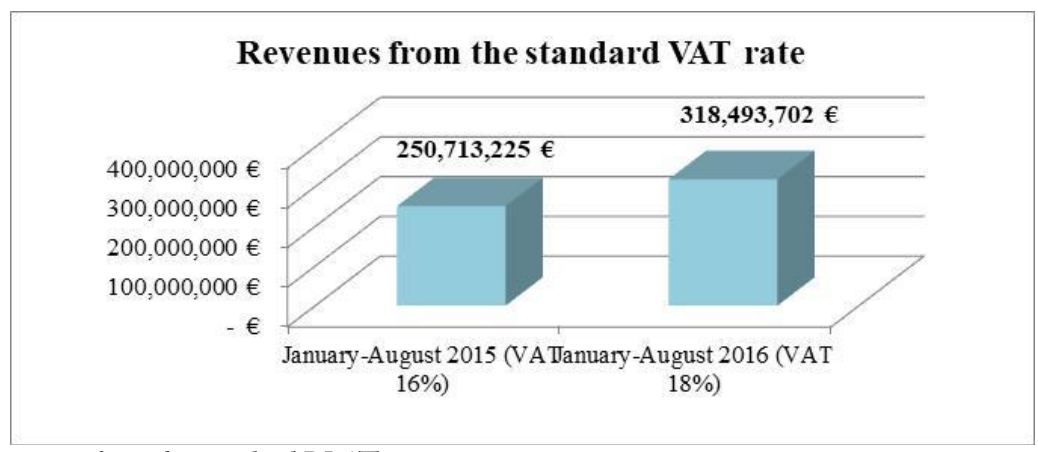

Figure 4: Revenues from the standard VAT rate

The increase of VAT has had a positive effect on TAK revenues too. In the period September-December 2015, TAK has collected about 6.5 million euro more VAT from the products/services in which VAT has been increased. If we take as a monthly average, then TAK revenues have increased by an average of about 1.6 million euro per month during this period. 
Table 2: Revenues from TAK

\begin{tabular}{|c|c|c|}
\hline \multicolumn{3}{|c|}{ TAK Revenues } \\
\hline September-December 2014 & September-December 2015 & Difference \\
\hline $\mathbf{4 1 , 1 6 2 , 5 1 9 €}$ & $\mathbf{4 7 , 6 8 4 , 6 2 0 ~} €$ & $\mathbf{6 , 5 2 2 , 1 0 1 €}$ \\
\hline
\end{tabular}

Source: Valbona Zeqiraj - TAK

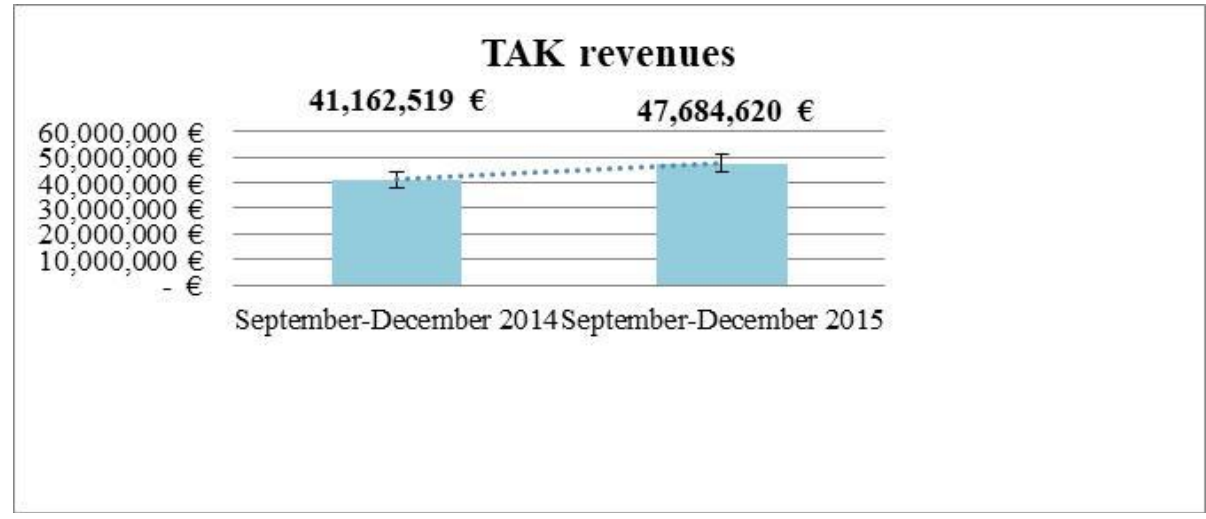

Figure 5: Graphical presentation of TAK revenues, based on legal changes

Other changes, VAT exemptions. As mentioned above, with approval from the TAK, production lines and the machinery for use in the production process, the raw material used in production process and information technology (IT) equipment, are exempt from VAT. Only domestic producers have the right on VAT exemption in raw materials, while only businesses that conduct IT activities in area of IT or dealing with resale of IT, have the right on technology exemptions.

The businesses have to apply to the TAK for exemptions. The total number of businesses that applied for VAT exemption on raw materials, during the period from December 2015 to September 2016 was 183, while the number of approved cases was 242.

The value of the import of raw materials exempted from customs in January-August 2016 was around 62.3 million euro or 10.2 million euro VAT. Regarding information technology equipment, 11 businesses have been exempted from VAT, while the value of imports exempted from VAT in customs was 1 million euro.

Table 3: VAT exemptions by Kosovo Customs January-August 2016

\begin{tabular}{|c|l|c|c|}
\hline No & Description & Value of import & VAT exemption \\
\hline 1 & Production lines and machinery & $26,266,520 €$ & $4,669,547 €$ \\
\hline 2 & Raw material for production & $62,455,649 €$ & $10,191,187 €$ \\
\hline 3 & Discharge free turnover for production & $1,543,009 €$ & $305,394 €$ \\
\hline 4 & Information technology equipment & $1,028,784 €$ & $86,102 €$ \\
\hline & Total & $91,293,962 €$ & $15,252,230 €$ \\
\hline
\end{tabular}

Source: Kosovo Customs

The VAT exemption for these products from does not present any loss to the budget, because in the past the same amount was reimbursed to businesses. But now, the 
businesses do not need to wait for VAT reimbursement until they sell their products. This increases the liquidity of Kosovar businesses and it may also have effect on efficiency increase. This is because the businesses are able to accumulate larger amount of raw materials in stock. In the absence of detailed financial data for businesses that have benefited from VAT exemptions, it is difficult to measure the effect on efficiency or cost of businesses. Based on TAK data, the turnover of businesses that benefited from VAT exemption has increased by about $5 \%$.

Another requirement of business regarding fiscal policies that impact on the cost of production is the removal of the customs tax on raw materials and the introduction of tax relief for new investments. Finally, the Government of Kosovo has exempted from customs tax the petroleum coke which is used as raw material especially by producers of construction materials.

\section{Reduce the Registration Threshold}

Having in mind lowering of informality and the inclusion of as many businesses as possible in VAT, in the applicable law the registration threshold of businesses for VAT has been decreased. In the previous law, if a business has made less than 50,000 euro income within a calendar year, it was exempted from the registration for VAT.

With changes in the fiscal package, a business should be registered for VAT if his turnover exceeds 30,000 euros, while for the part of turnover which exceeds this amount VAT will be applied.

Reimbursement- Since the entry into force of the reform, the number of registered businesses for VAT has been increased significantly. Prior to the entry into force of the applicable law, the monthly average of new businesses registered for VAT was 163, while, after entry into force the average has been increased to 326. Even though the reduction of the VAT threshold may increase bureaucracy for small businesses, this change is supported by representatives of business, because it reduces the informality, by the fact that more businesses are included in the declaration of VAT.

With the legal basis (new administrative instruction), if according to the Tax Administration's assessment, a business overrides the VAT refund claim, then the same party is obliged to submit a new application or request for credit for the following periods. This is an additional requirement to what is regulated by law.

Also this restriction causes a problem for businesses because the reimbursement procedure may be prolonged. The request for reimbursement may take long time due to the review by TAK regional and central officers. Finally, another problem for businesses is also the fact that a payment should be made in the same billing period in order to claim for reimbursement.

\section{Other Fiscal Changes in Kosovo}

Always, based on the Government Decision of the same meeting on date 23 March 2015, the Kosovo Government also decided to amend the Law on Corporate Income Tax (CIT) and the Law On Personal Income Tax (PIT).

From January 2009, the corporate income tax rate in Kosovo has been reduced from 20 
to $10 \%$.

From 1 January 2010, the Kosovo Government through its new law on CIT removed the tax on dividends received by resident and non-resident taxpayers, while the corporate income tax rate remained $10 \%$.

In the changes or fiscal reform of 2015, the Government of Kosovo has reinstated the $10 \%$ tax on dividend for the Corporate Income Tax CIT, while Corporate Income Tax $(10 \%)$ remained unchanged from the 2010 Law.

It is worth noting that the tax on dividend is charged at the time of payment or crediting. So if the shareholder decides that the dividend be reinvested then the legal entity is exempted from the tax.

Basically, this policy promotes the growth of capital investment and creation of the new jobs. But if we refer to a study made by the UNDP with the four largest manufacturing industries, it has been found that halving of taxation on corporates from $20 \%$ to $10 \%$ in 2009 , didn't have any effect on the growth of these industries. ${ }^{4}$ Therefore, this change is not expected to have any major effects on the growth of corporate investments operating in Kosovo.

Although the establishment of dividend taxation may not have any effect on businesses, this tax ensures equality between persons who generate wage income and are taxed according to the law on PIT and those who have dividend income.

While so as the fiscal reform package, the reports on the Law on Personal Income (PIT) have had impacts too. This law does not have any substantial change in the tax rate.

The ones I value in this new change are:

- The maximum amount of excluded expenses for training has been increased from one thousand to three thousand euro, if they are conducted abroad;

- Allowable expenditures for reduction of representation are decreased from two to one percent;

- Allowed reductions for charity activities have increased to $10 \%$ etc.

\section{Conclusion}

Increasing VAT on most products from 16 to $18 \%$, by keeping other factors isolated, is expected to bring a price increase in customer basket and increase of budget revenues. Herein we can conclude that, based on the previous reductions of corporate tax, the taxation of the deferred dividends is not expected to have any effect on the increase or decrease of investments.

The biggest changes with regard to fiscal reform affect the VAT law, where the VAT threshold is lowered from 50,000 euro as it is by the current law to 30,000 euro. So every business that generates turnover above 30,000 euros within a year will be forced to register for VAT and to pay for the part that exceeds this amount.

Kosovo's budget will benefit from this decrease in VAT threshold, since a larger number of businesses will be forced to pay VAT, but on the other hand this fiscal policy will be a burden on new businesses that are in need of fiscal facilitations and potentially create new jobs. Based on the responsibility of the Tax Administration of Kosovo (TAK), the

\footnotetext{
${ }^{4}$ UNDP, Impact of Tax Regime on Four Manufacturing Sectors, 2014, Source: http://bit.ly/1QpOozr
} 
number of businesses that paid VAT in 2014 was 14,560, while the decision to lower the threshold would increase this number for 1,800 businesses.

Table 4: Number of business with VAT before and after fiscal reform

\begin{tabular}{|l|c|c|c|c|c|c|}
\hline Year & 2010 & 2011 & 2012 & 2013 & 2014 & RF 2015 \\
\hline No. of businesses & 8,834 & 9,605 & 10,556 & 12,327 & 14,560 & 16,360 \\
\hline
\end{tabular}

The other change, which is expected to have an opposite effect to that of lowering the threshold for the payment of VAT, is the VAT exemption for following categories of products:

- Production lines and the machinery for use in the production process;

- The raw material used for the production process; and

- Information technology equipment.

To have a realistic answer to the real impact of fiscal reform in 2015, we can say that:

- Reduction of VAT thresholds from 50,000 to 30,000 euro is expected to exacerbate small businesses that are largely generating jobs.

- The reduction of VAT on production lines and on raw materials can boost the investments in production and can make domestic products cheaper on internal and external markets.

- Despite the positive impacts on lowering prices of some products, the escalation of VAT is expected to increase the cost of living of Kosovo citizens.

- This increase in the cost of living will reflect on larger budget revenues in order to balance budget needs, economic development and cost of living.

\section{References}

Nimani, Artan (2010) Menaxhimi i Financave Publike, KUB Prishtinë

Harvey S. Rosen (2010) Financa publike, UET Press, Tirane

HYMAN, David N( 2010) Public finance, a Contemporary Applikation of Theory to Policy, Cengage Learning. North Karolina, State University. USA

HENDERSON,David (2007): Klasikët e mendimit

Govori, F dher Nimani A (2010) Financa, IFK Prishtinë

Gazeta Zyrtare, Ligji nr. 05/L-037 për tatimin mbi vlerën e shtuar, Neni 29: http://bit.ly/2e6J19w

Ministria e Financave, Intervistë me Semra Turbedar dhe Berat Havolli, 24 Prill 2015.

Vendimi Nr 01/176. Qeveria e Republikës së Kosovës, 10 Mars 2014, http://bit.ly/1BqCRr1

Fondi Monetar Ndërkombëtar, Kosovo: Concluding Statement of the 2015 Article IV Mission, 30 Mars 2015, http://bit.ly/1FccDJt

Strategjia e MF mbi Reformes fiskale viti 2015

Rregullorja Nr.2004/51,Mbi tatimin në të ardhurat e korporatave, Prishtinë 2004.

Doracaku mbi tatimin në të ardhurat e korporatave në Kosovë, Prishtinë 2005.

Rregullorja Nr.2004/52,Mbi tatimin në të ardhurat përsonale në Kosovë ,Prishtinë 2004.

Udhëzim Adm.Nr.02/2005, Për zbatimin e tatimit në të ardhurat përsonale në Kosovë,Prishtinë 2005.

Doracaku i tatimit në të ardhurat përsonale në Kosovë, Prishtinë 2005.

Ligji ,Nr.2004/48,Për Administratën Tatimore dhe Procedurat, Prishtinë 2005.

Udhëzim Adm.Nr.05/2005,Mbi implimitimin e ligjit ,Nr.2004/48,Mbi Administratën Tatimore dhe Procedurat ,Prishtinë 2005.

Ministria e Ekonomis dhe Financave ,Buxheti i vitit 2005, Prishtinë 2005.

MEF-i ,Aktualitetet fiskale dhe raporti i analizave të rrjedhave ekonomike:Janar-Gusht 2005, Prishtinë 2005. 